\title{
BOCCACCIO Y DANTE EN EL CURIAL E GÜELFA
}

JULIA BUTIÑÃ JiMENEZ

\section{BOCCACCIO:}

Si, pero con reservas

Un autor como el del Curial, que escribe con realismo y humor, próximo al humanismo italiano, forzosamente tenía que haberse embebido de los cuentos del certaldés. De él habria aprendido las principales lecciones: el amor de la realidad, el gusto por el sensualismo, el aunar influencias y estilos. Estos factores, más el humor, no ya oportuno sino exacto, hacen la literatura agradable, a lo cual aspiraba Boccaccio: «Amorosas damas, si yo he bien comprendido la intención de todas vosotras, nos hemos reunido aquí para consolarnos y alegrarnos relatando"' ${ }^{1}$. Según este autor, tal prosa es una forma de consuelo (asi los relatos divertidos en un ambiente de desolación provocado por la mortal epidemia que asolaba a Florencia) y sirve para alejar a las mujeres de la tristeza ${ }^{2}$. Placer y consolación a que también aspiraba el escritor catalán: «a vostra consolació e plaer recitaré» ${ }^{3}$.

' Decamerón, Barcelona, ed. Planeta, 1982, p. 40. (Sigue la versión castellana de 1496, actualizada por $\mathbf{M}$. Olivar).

2 Ibidem, p. 619.

"Curial e Güelfa, vol. I, «Els Nostres Clàssics», Barcelona, ed. Barcino, 1930, p. 55. Estos dos factores son evidentes en el Curial. Y con ellos tenemos ya las funciones básicas de la novela como género: provecho y placer. Con ellas se supera la tradicional dicotomía de la literatura y la consiguiente consideración que las obras de distracción eran, si no pecaminosas, inútiles. (Para esta doble función de la novela, véase E.C. RıLEY, Teoría de la novela en Cervantes, Madrid, ed. Taurus, 1972, p. 135 y ss.). 
No es quimérico, pues, reconocer como fuente el inicio del Decamerón, en un fragmento que es propiamente una proclama del derecho al placer y a la liberación sensual - siempre dentro de la honestidad-, cuando el autor catalán es tan próximo a esta sensibilidad que algunas escenas suyas están impregnadas de sensualidad $\mathrm{d}^{4}$.

Que el autor del Curial había bebido en Boccaccio era sabidos. Que lo corrige es un hecho comprobado en la novela $6 .{ }^{a}$ de la II Jornada, que es la fuente de los sucesos del inicio del III volumen, desde el ataque del corsario hasta la liberación de Túnez $z^{6}$. La corrección es minuciosa: rectifica -con lógica histórica, aunque sin acierto- que fuera Manfredo quien gobernaba en Sicilia en tiempos del rey Pedro el Grande.

Esta actitud hacia el certaldés, de evidente admiración por el estilo y agilidad de la trama, como muestra el aprovechar su cauce argumental, contrasta con algunos pequeños detalles en los que parece oponérsele. Observémoslo en un pasaje, que propongo como fuente de inspiración del tan conocido episodio de las monjas. Ahora bien, nuestro novelista es maestro en el arte de la disimulación, que caracteriza al humanista, y no hallamos un calco exacto: hay una situación homóloga en espíritu, pero sostenida sólo por minúsculos puntos de apoyo en el texto italiano.

Recordemos que en la introducción de Boccaccio las doncellas comentan cómo, junto con la epidemia, ha llegado la corrupción a la ciudad, incluso entre «las monjas claustrales y encerradas»? . Ello les servirá de justificación para un deleite sano, como es solazarse con sus relatos, con lo que huirán honestamente de la muerte que les angustiaba. La crítica de la represión de las mujeres y de los prejuicios sociales - presente ya en el proemio de la obra italiana - se aviene con el autor catalán, cuyos personajes femeninos, aunque honestos, no reprimen sus impulsos naturales. Esta disposición anímica tan próxima podría haber determinado la desenvoltura de las monjas francesas que en la novela caballeresca manifiestan tan libremente sus deseos eróticos. Simplemente recordemos un comentario que les hace Fiesta, la

${ }^{4}$ Es proverbial ya la exquisitez erótica de la descripción de la habitación de Laquesis o el apasionado beso de Cámar, en cámara lenta para los sentidos. Y traduce también un rico contexto valorativo del factor hedonista el detalle psicológico que asemeja Güelfa a Guismunda (véase el relato a que remite la nota de Aramón, en la edición citada del Curial, vol. III, p. 260).

5éase, además de la nota citada supra, la p. 267

"Véase J. BuTiñA, "Tres comentaris sobre el Curial e Güelfa", Revista de Filología Románica 8 (en prensa), trabajo que como éste se deriva del libro Sobre las génesis del "Curial $e$ Güelfa), que espero poder publicar en breve.

${ }_{7}^{7}$ Véase la edición citada, p. 16. Y también la versión catalana del siglo xv: «en són molts d'aquells tals, qui sens fer distància ninguna de les coses honestes a les qui són deshonestes, sol que l'apetit los venga, a soles e acompanyades, de dia e de nit, fan allò que mayor delit los torna. E no solament les persones soltes, ans encara les reciuses dels monestirs). (Decameró, vol. I, «Els Nostres Clàssics», Barcelona, ed. Barcino, 1926, p. 52). 
acompañante de Curial: "yo os veo de tal pelaje que aún esta noche os jugariais a puñadas cuál de vosotras le tendria»".

Pero si enfrentamos los pasajes se reconocen tan sólo unos pequeñísimos contactos. Así, mientras Boccaccio sitúa el comienzo de su narración -no el desarrollo, como distingue- en una iglesia, el catalán sitúa - con menos prejuicios aún - la escena dentro de la línea narrativa y en un monasterio. Son elocuentes especialmente los detalles más insignificantes: mientras que el certaldés esconde los nombres de las mujeres que se solazan con relatos tan desenfadados', el autor catalán —que se complace a menudo en ser osado-nos puntualiza, con mucho detalle, cuando en rigor no sería preciso hacerlo, todos sus nombres y apellidos: «Juanina de Borbón, Violante de la Sparra, Isabel de Bar, Blanca de Bretaña, Catalina de Orleáns, Marta de Armagnac y Beatriz de Foix, todas reunidas fueron a la cámara, y allí todas se hicieron extrema fiesta, y con tanta alegría que no se puede escribirn ${ }^{10}$. Nombres que además corresponden a las mejores familias de Francia ", al igual que las del Decamerón son "cada una de ellas de noble linaje»" ${ }^{12}$. (Esta sencilla explicación podría verse favorecida también por la vía muerta a que había llevado la minuciosa investigación onomástica) ${ }^{13}$.

Establecer esta relación creo que facilita la comprensión para el hecho de encontrar en una narración y montaje plenamente caballerescos, como es el II libro del Curial, la inserción no muy normal de un episodio tan puro de humor erótico. Como tampoco son fáciles de entender los pasajes alegóricos que en el III interrumpen la línea narrativa y a los que seguidamente nos referiremos, pero que responden asimismo a una fecunda motivación. $Y$ en cuanto al aspecto formal, así como asimila haciéndola distinta la alegoría dantesca ${ }^{14}$, así habría reflejado el realismo sensual boccacciano de una manera tan suave y difusa como exacta.

Una salida parecida a ésta de los nombres de las monjas, pero a la

${ }^{8}$ Curial y Güelfa, Madrid, ed. Alfaguara, 1982, p. 145 (traducción de P. Gimferrer), edición que seguiremos.

${ }^{9}$ "Sus nombres pondría yo aquí en su propia forma, si justa causa no me disuadiera; y la causa es ésta: que yo no quiero que por lo que se relatará en lo que se sigue de aquí adelante, alguna de ellas pueda ser reprendida, ya que en tiempo de tanta aflicción, como se ha dicho, las excelencias de la honestidad se hallaban sometidas al placer y al esparcimiento" (Decamerón, op. cit., p. 15).

${ }^{10}$ Curial y Güelfa, op. cit., p. 146. Véase también la p. 144, en la que Yolanda le Meingre alega a su familia «de asaz buena nombradía».

"Véase M. DE Riquer, Història de la Literatura Catalana, vol. II, Barcelona, ed. Ariel. 1964, p. 623.

${ }_{12}$ Decamerón, op. cit., p. 15.

${ }^{13}$ Véase A. EsPadaler, Una reina per a Curial, Barcelona, ed. Quaderns Crema, 1984, p. 122.

${ }_{14}$ Véase el trabajo citado en la nota 6, donde se muestra la correspondencia de los tres diálogos del Curial con pasajes de la Divina Comedia. 
inversa, se daría con los nombres de las Artes Liberales, que de una manera tan desconcertante se omiten en la segunda visión mitológica del Curial ${ }^{15}$. En Genealogía de los dioses paganos, obra que la crítica contemplaba ya como fuente de la novela caballeresca, en un ataque de Boccaccio a los ignorantes -que concreta especialmente en los juristas ${ }^{16}$ - , dice que aquéllos creen conocer las Artes Liberales «de las que muy a menudo no conocen ni los nombres» ${ }^{17}$. Esta alusión no tendría validez si no fuera porque se inserta en el libro XIV de la Genealogia, el cual parece dar explicación a otros puntos de la tan interesante como extraña introducción del autor catalán a su libro III.

Tengamos presente que el autor catalán se reconoce a sí mismo con el mismo calificativo de ignorante: «a mí y a mis iguales como a ignorantes [las Musas] tienen en singular aborrecimiento" ${ }^{18}$. Y tengamos presente a la vez que el tan virulento ataque del certaldés se funda en que aquellos incultos se hacen los entendidos en materia de poesía.

Observemos que el catalán no hace como los ignorantes de Boccaccio que - según dice- se atreven a atacar a las Musas. Él tiene una postura humilde (ni osa invocarlas, muy ladinamente) y acata la parafernalia olímpica (aunque con humor, como muestra la casi grotesca figura de Fortuna).

¿Qué aspecto en materia de Poética podía irritar en este libro tanto al autor del Curial, si es que verdaderamente está respondiendo irónicamente a aquel ataque? Boccaccio dibuja aquí su concepto poético de ficción, según el cual está permitido alterar la verdad ${ }^{19}$ —como también para el Marqués de Santillana ${ }^{20}$ - y que expone claramente en el capítulo 13 del mismo libro XIV, donde sin embargo mantiene que Los poetas no son embusteros (es el título del capítulo). Pero es plenamente consciente de la desfiguración de temas como el de Dido ${ }^{21}$, tema que precisamente toma como símbolo de la

is Véase este pasaje en las pp. 429-433 de la edición del Curial que seguimos. Sobre las rarezas del mismo, consúltese L. BADíA, "La segona visió mitològica de Curial: Notes per a una interpretació de l'anónim català del segle XV Curial e Güelfay, en Miscel. lània Antoni M. Badia $i$ Margarit, Publicacions de l'A badia de Montserrat, 1987, pp. 265-292.

16 Remito a la hipótesis de autoría de J. BuTIÑA, "Sobre l'autoria del Curial e Güelfa", Boletin de la Real Academia de Buenas Letras de Barcelona. XLI, 1987-1988, pp. 63-119, ya que el autor que se propone es un jurista. Tengo que alegar a favor de este último supuesto que el dr. Solé Durany está profundizando en el mismo, en función a las múltiples referencias juridicas que ha encontrado en la novela.

${ }_{17}$ Genealogia de los dioses paganos, Madrid, Editora Nacional, 1983, p. 801.

18 Curial y Güelfa, p. 322.

19 Véase Genealogia de los dioses paganos, p. 816 y ss.

${ }^{20}$ Remito a «La Comedieta de Ponça y el Curial e Güelfa frente a frente», que publicaré en la Revista de Filología Española.

${ }^{21}$ Véase Genealogía de los dioses paganos, pp. 162-163, y en el mismo libro XIV, pp. 838840. Queda manifiesto aquí que Boccaccio distingue claramente el concepto histórico del estético; el autor del Curial, si estaba replicando, lo que hacia era no aceptar la concesión artística hacia la veracidad. 
deformación literaria permitida de la verdad, y tema que precisamente, con un punto de vista opuesto, enervaba profundamente al autor catalán, como bien muestra el primer sueño mitológico ${ }^{22}$.

Para Boccaccio, al contrario, las obras de la antigüedad eran tabúes. Según la Genealogía se puede atacar los errores del mundo pagano, pero no sus bellas obras de arte ${ }^{23}$. Nuestro novelista, en cambio, se opone al arte de los grandes clásicos en cierto modo: se niega a aceptar una Poética no veraz, por excelsa que sea.

Pensemos que estamos en el punto inaugural, tocando los orígenes de la famosa polémica sobre Dido en las literaturas hispánicas. No se trata pues, tanto de adherir el Curial a una corriente concreta ${ }^{24}$ como de reconocer una actitud personal: la de testimoniar la autenticidad de su relato ${ }^{25}, 0-0$ además - la de mantener una teoría literaria. Nuestro autor no veía en Dictis y Dares la deformación legendaria de la tradición, como vemos hoy, sino la objetividad frente a las interesadas o subjetivas deformaciones en nombre del Arte, como la de Homero. Recordemos que lo que preocupa a Apolo, en un caso paralelo al de Dido, en que se defiende a Héctor por encima de Aquiles, es qué escritura "es más verdadera» y, al final de este primer sueño, se condena audazmente a Homero por escribir más para lucirse que para reproducir la verdad.

Boccaccio defendía la licencia poética porque dice la verdad con un velo, mientras que en el Curial, si se deforma ésta, el principio es inaceptable. La verdad es una: Homero y Virgilio fingieron cosas que no fueron, adornadas con colores retóricos; por lo tanto, son condenados en la primera visión mitológica. El autor del Curial dora los hechos de plata de su héroe, como habian hecho los grandes escritores, según dice; pero debería parecerle inadmisible que - como en el caso de Dido - se hiciese al revés. Por gran escritor que se fuera no se deben tornar de plata los hechos dorados. Esta confrontación es mucho más profunda, pero limitémonos a observar que para nuestro autor el realismo exige una profunda veracidad ${ }^{26}$; para Boccaccio el realismo sólo es subsidiario de la estética.

${ }^{22}$ Puede seguirse en las pp. 362-377 de la edición que seguimos.

${ }^{23}$ Véase Genealogia de los dioses paganos, p. 866.

${ }^{24}$ Véase M. R. LIDA DE MALKIEL, Dido en la literatura española, Madrid, ed. Castilla, 1974 , p. 111.

25 Para Ercilla en la Araucana (véase la obra de Lida de Malkiel, pp. 127-134, el relato de Dido constituye una importante interpolación con la cual testimonia el autor su verismo. Este poeta lo hacia a fin de defender a los indigenas. De una manera parecida el autor catalán podía estar defendiendo encendidamente a Dido sin implicaciones concretas de medievalismo eclesiástico.

26 La manera veraz de escribir nuestro autor se podría aproximar a la tercera que expone Boccaccio en cuanto a los modos de ficción (véase la Genealogía, pp. 823-824) y que se parece más a la Historia que a la fábula y de la que se sirvieron Virgilio y Homero (precisamente los autores que aparecen en el Parnaso en el Curial): «piensan bajo el velo de la ficción algo muy 
Tan importante era para el autor del Curial que resalta el concepto - lo hace llamativo para obtener una mayor efectividad - por medio de una imagen: la de Apolo en el Parnaso. Como también era importante el valor del estudio y la ciencia, para lo cual recurrió a la segunda figuración: la del dios Baco, y a la que nos referiremos posteriormente.

Boccaccio también había representado su concepto con una imagen. Interesa ponerlas de lado, ya que el presentar puntos de coincidencia con la tan extraña segunda visión del Curial nos hace plantearnos si ésta, inspirada en la boccacciana, representase de una manera gráfica el enfrentamiento que estamos insinuando.

En el capítulo 5 del mismo libro XIV explica Boccaccio que hay una casa en la Tierra, a imitación de la asamblea celestial, dedicada a los estudios, donde encima de un trono preside todo la Filosofía. Y en el Curial tenemos a ésta, bajo el curioso nombre de Baco, dominándolo todo y en unos palacios grandes y muy ricos.

Según Boccaccio: «cubierta de regios vestidos y engalanada de oro, no de otro modo que como emperatriz de los mortales, con su mano izquierda sujeta los libros, con su derecha lleva el cetro real (...) Y alli entre otras cosas muy dignas de la mayor veneración, hay allí detras de la soberana colocados en una sede muy elevada unos hombres (...) que más creerías que son dioses que mortales». Éstos equivaldrían a las Artes, situadas delante del dios Baco y personificadas en reinas en el Curial. Pues, en esta novela, las reinas-Artes que acompañan al dios tienen delante suyo unas doncellas muy bellas que dan la pista por sus carteles de ser las diferentes ramas de las Artes Liberales ${ }^{27}$.

Según Boccaccio: «Éstos [los hombres casi dioses], ya llenos de las enseñanzas de la que gobierna, llevan hacia otros con abundancia lo que han conocido. Hay además otra multitud estrepitosa de diferentes clases de hombres».

Y en el Curial, «Detrás de aquel dios había tanta gente y de tan diversas partidas y de tan extrañas tierras, que a no ser porque todos hablaban latín,

distinto de lo que se muestra. Además los cómicos más honestos, como Plauto y Terencio, también utilizaron esta especie de hacer fábulas no pensando otra cosa que lo que la letra significa, pero queriendo descubrir con su arte las costumbres y palabras de distintos hombres y entretanto enseñar a sus lectores y hacerlos cautos. $Y$ si estas cosas en realidad no existieron, puesto que son comunes pudieron ser o podrian serlo". Según Aristóteles esto es precisamente lo que caracteriza a la ficción frente a la historia (ibidem, nota 474). Es similar también - según Boccaccio- a las parábolas del Evangelio; es decir, es exactamente lo que se dice, pero ha de descubrirse el significado, oculto pero no alterado.

${ }^{27}$ Una diferencia a constatar: en Boccaccio eran hombres, como dioses, mientras que en el Curial son reinas, precedidas por doncellas. El catalán seguía por tanto la linea tradicional, según la cual eran del sexo femenimo. Así pues, cabría preguntarse si le estaba volviendo a enmendar. 
nunca se habrian entendido", que correspondería a la muchedumbre estrepitosa de gente diversa del certaldés.

Son pequeñas diferencias. Así, fijémonos en esta multitud, que para Boccaccio está integrada por hombres de ánimo soberbio e «inflados con un cierto fasto (...), se inflan con tan gran hinchazón que al andar desean ser señalados con el dedo". Y son obviamente los juristas ${ }^{28}$. Y observemos también que es una crítica parecida a la que se hace en el Curial contra los que presumen de dominar la ciencia alegórica, que son «soberbios... y tienen el pecho hinchado, como si aquella ciencia ocupase mucho lugar y en los pechos no les cupiese», al principio del III volumen.

Ahora bien, hay que preguntarse a quién podia referirse el Curial: ¿quiénes son los que hablan latín y se encuentran en todos los países? ¿No podría estar aludiendo a los juristas, a los que defendiera bajo una perspectiva opuesta y objetiva, la de universalidad?

Es decir, la visión de Boccaccio, situada en el punto neurálgico de la exposición de su Poética, en la que defiende la deformación virgiliana de la verdad, recuerda en algunos puntos el paisaje alegórico de la visión del Curial, en un punto cumbre del III volumen, donde se ha condenado tal deformación. En ambas, la Filosofia domina a las otras Ciencias -ello no sería de extrañar-, pero el gentio que les acompaña es de muy distinta valoración en cada autor.

Según el certaldés aquellos hombres atacan a los poetas y a las Musas, "dicen que sus poemas son demasiado oscuros, engañosos, llenos de lascivias, repletos de banalidades y de tonterías de los dioses paganos, poemas que afirman que Júpiter, como hombre adúltero y sucio, es ahora padre de los dioses, ahora el rey de los cielos» ${ }^{29}$. Y el autor catalán, escéptico en cuanto a la ayuda de las Musas, sin hacer una invectiva directa contra los dioses paganos, que tanto endiosaba Boccaccio, muestra crudamente sus lascivias en boca de la heroína mora y de la diosa Fortuna, en un lenguaje que entendía todo el mundo. Sin ninguna virulencia, pero con hábil efectividad - según es característico de su estilo-, desprecia el dominio hegemónico y tiránico de las favoritas de Apolo. Y burla así muy diplomáticamente al reverendísimo Olimpo.

Él - recordémoslo - se reconoce «imitador de las míseras y gárrulas hijas de Piérides, enemigas capitales de aquellas nueve egregias hermanas que habitan en el Monte Parnaso" ${ }^{30}$. Por lo tanto, es similar al sátiro Marsias, que había sido audaz y temerario con Apolo, ya que le había desafiado

28 "presuntuosamente comienzan a pasear por las ciudades, a mezclarse en los negocios seculares, a dar consejos, a tratar matrimonios, a estar en los banquetes, a dictar las tablillas de los que hacen testamento" (Genealogia, p. 812).

${ }^{29}$ Ibidem, p. 813.

${ }^{30}$ Curial y Güelfa, op. cit., p. 322. 
como músico a tocar la flauta, por lo que fue desollado vivo. Nuestro autor se atrevía a emular a las Musas sin ser apto para hacerlo. Parece lógico que esté a su lado Baco, el dios que protege a Marsias, según cuenta la Genealogía de los dioses paganos.

A la anécdota del sátiro también se refiere Dante antes de entrar en el Paraiso (versos 16-22), al recabar para ello la ayuda de Dios. Si Dante necesitaba la protección divina al introducirse en el punto más sublime, como reconoce allí mismo, el autor del Curial - siempre unos grados más profano que Dante- recurriría a la de Baco. Este dios, que propiciaba la libertad y atrevimiento de Marsias, cuya imagen presidía las ciudades libres en señal de su libertad y cuya denominación latina es Pater Liber, y que usurpa el lugar al dios de la elocuencia, a Mercurio, es idóneo para una Poética que no se subyuga a las Musas.

$Y$ un detalle más, al que hay que atender ya que dificilmente deja un cabo suelto el autor catalán: este dios ocupa una colina del Parnaso; la otra es de Apolo. Los dioses que presiden los dos hitos mitológicos del Curial.

Y sabiendo que los significados en esta novela se superponen hay que atender al hecho que acabamos de mencionar y que había observado ya la Dra.Badia: que Baco quita de su solio a Mercurio en la presidencia de las siete Artes Liberales ${ }^{31}$. Y que Mercurio es el dios que había reprendido eficazmente a Eneas, como la riña de Baco será la que consiga la redención moral de Curial. No es ésta la primera ocasión en que se ha visto que Curial se asemeja al héroe clásico; y en este orden de cosas, el rodeo por Baco podía ser oportunísimo para simular con gran veracidad ${ }^{32}$. Además, esta interpretación incide con la de otorgar a la novela el tono de advertencia, al que cada vez parecen inclinarse más los análisis.

El nombre del bonachón e inofensivo dios del vino podía —según parece - reunir motivos de semántica y de retórica. También puede ser conveniente considerar que con ese nombre se aludía a la locuacidad de los ebrios, que es la de Marsias ${ }^{33}$. ¿Quién sino podía atraverse a alborotar así la rígida y sacrosanta estabilidad del Olimpo?

"11 Art. cit., p. 275.

${ }^{32}$ Entresaco de la famosa reprimenda de Mercurio a Eneas: "Ahora tú, aquí echas los cimientos de la alta Cartago, y, esclavo de tu mujer, construyes una hermosa ciudad, olvidado jay dolor!, de tu reino y de tus cosas. (...) ¿con qué esperanza pierdes el tiempo en las tierras de Libia? Si ya no te mueve la gloria de tan grandes hechos ni emprendes trabajo alguno en loor propio..." (Eneida, Madrid, ed. Aguilar, 1988, p. 121). Según la identificación de Curial con Alfonso $V$, que he expuesto en diversas ocasiones, el símil era idóneo en sus últimos años, según se recoge por testimonios históricos. Y en consecuencia sería preciso disimular.

${ }^{33}$ Dice Boccaccio que por la temeridad de Marsias entiende «la locuacidad de los ebrios que se dirige contra alguno, por lo que a la vista de los incultos a menudo los sabios parecen confundirse con ignorantes" (Genealogia de los dioses paganos, p. 344). Según la identificación mencionada en la nota anterior, ¿quién podría formular un alegato semejante sino un ebrio? 
La Dra.Badía admira esta osadía, así como también la inusitada revisión crítica que ejerce implacablemente el Curial sobre los clásicos: «una admirable gosadia que potser només tenien, al segle $\mathrm{Xv}$, els qui estaven només parcialment tocats del corc del pre-humanisme $)^{34}$. Cerramos el punto de Boccaccio, pues, insistiendo en la magnifica libertad del novelista catalán, a quien ni esclavizó la cultura que tanto veneraba.

\section{DANTE}

Tras la cita de san Gregorio en boca del dios Baco

Como bien sabía el autor del Curial $^{\text {ss }}$, la fiera - la pantera que simbolizaba la lujuria - que impedía el paso a Dante en la Divina Comedia era temible, insaciable y asesina: «no permite a nadie pasar por su camino, y para impedirlo lo mata. Tiene una naturaleza tan malvada y ruin, que nunca satisface su hambre voraz y siente más apetito después de comer que antes $)^{36}$.

Ante tal peligro, Virgilio se ofrece como guía a Dante para llevarlo al Paraíso: «Por eso he pensado y decidido, por tu bien, que me sigas. Seré tu guía" (versos 112-113).

En función del paralelismo de los tres diálogos puros del Curial con tres pasajes de la Divina Comedia $a^{37}$ —el Infierno, del Purgatorio y del paráso terrenal-y de la idea general de purgación del III volumen de la novela, habría que considerar si ésta $-\mathrm{y}$ muy especialmente el III libro- mimetiza este proceso de Virgilio y Dante en los personajes de Melchor de Pando y Curial. La actitud didáctica que muestra el autor, especialmente a comienzos del III volumen, y el concepto mismo de amistad, al que ha remitido con la cita del libro IV de la Ética a Nicómaco ${ }^{38}$, permiten pensar que esta

¿Quién sino hablar tan crudamente a un casi emperador? ¿No son los beodos los únicos que, como los bufones en las cortes o las personas alienadas, osan decir las verdades?

34 «De la 'reverenda letradura' en el Curial e Güelfa», Caplletra 2, 1985, p. 18. (Se trata también aquí de la relación insinuada entre Eneas-Curial).

${ }^{35}$ En el Curial se hace referencia a este pasaje dantesco (p. 120 de la ed. Alfaguara).

${ }^{36}$ Obras Completas, BAC, Madrid 1980, p. 24, por la que citaremos. (Es el canto I del Infierno, versos 95-99).

${ }^{37}$ Remito a la nota 14.

38 Tengo que enviat nuevamente a "Tres comentaris sobre el Curial e Güelfa". Y para la novela caballeresca, véase la p. 360 de la edición que seguimos. 
relación sea, reflejo del papel de mentor de Virgilio con el poeta ${ }^{39}$. Beatriz encargó el oficio de guia al gran latino a fin de conducir a Dante, al igual que durante toda la novela catalana encarga Güelfa a Melchor que ayude a Curial. Y ambos pasarán así el Infierno.

Se puede establecer, por ejemplo, otra comparación al final de ambas obras: la satisfacción ante la tarea cumplida del viejo amigo Melchor viendo a Curial casado y feliz recuerda la pérdida del sublime vigor de la fantasía de Dante, iluminado ya por el resplandor que le dejaba satisfecho. Ambos maestros han cumplido su labor y dejan de escribir complacidos. Los dos protagonistas se hallan ante la visión del Amor.

Pero interesa aquí centrar la atención en la figura del vencedor de la fiera, que se dibuja proféticamente en esta introducción al viaje dantesco, en el canto I del Infierno ${ }^{40}$.

Dice Dante que a esta fiera sólo la aniquilará el can: «hasta que venga el mastín que le dé dolorosa muerte» (versos 101-102). Y a continuación hace la descripción del héroe: «Él no se alimentará ni de bienes de la tierra ni de metales, sino de sabiduría, amor y virtud, y su patria estará en la pobreza. Será salud de aquella Italia humilde por la que murió la virgen Camila, y heridos Eurialo, Turno y Niso. Echará a la bestia de un lugar a otro hasta que la arroje al infierno, de donde la sacó la envidia» (versos 106-111).

Apliquemos al Curial estos versos. El héroe de la fiera no se alimentará de tierras ni de riquezas. A lo que se yuxtaponen los consejos del desprecio por los bienes terrenales en boca del fraile Jabalí a comienzos del III volumen. Que se nutra de sabiduría, amor y virtud podría considerarse una receta común para estos caballeros de armas y letras. Por lo que no puede tenerse por sintomático el que sean los rasgos de Curial en este volumen.

El nombre de Camila presenta parecido con el de Cámar. En el argumento sentimental Cámar se superpone a la heroína de la Eneida, a Dido, según ya vio la Dra. Badía ${ }^{41}$, pero los rasgos del carácter de la mora en la obra catalana son propios de la virgen Camila; en la epopeya latina ésta hace un papel que mezcla ternura y gracia femenina con fortaleza moral, y muere joven con una herida en el pecho. Y ella no es la protagonista de la obra. Hagamos atención a otro posible simbolismo: Cámar significa luna; quien tiene auténticamente la luz es otro astro, el sol. Como en la novela es otra la verdadera heroína: Güelfa. citada.

${ }^{39}$ Véanse los cantos II y XII del Infierno, pp. 27-30 y 76 respectivamente de la edición

${ }_{40}$ Tengamos presente que esta profecia se inserta en un pasaje que conocía bien el autor del Curial. ya que además de haberlo citado (nota 35), lo habría empleado como bastidor precisamente en el diálogo correspondiente al infierno de su obra, diálogo que tiene lugar entre Melchor y Curial y es introductorio al III libro.

${ }^{41}$ Véase «De la 'reverenda letradura' en el Curial e Güelfa», art. cit., pp. 16-18. 
Ahora bien, si Camila murió víctima por causa de Eneas, como Cámar por Curial, se plantea la posibilidad de que el autor estuviese aplicando a su protagonista las características del héroe troyano que ya reflejaba Dante en su profecía ${ }^{42}$. Que pudiese adjudicar a Curial los rasgos mesiánicos que anunciaba Dante para Italia en un restaurador de la justicia y la paz, también con el telón de fondo de la Eneida. Que representase el pacificador ${ }^{43}$ para aquel momento tan angustioso de una Italia rota y desangrada en largas y estériles guerras. Como había sido vencedor Eneas, sobre Eurialo, Turno y Niso.

Con lo cual la identificación de Curial con el Magnánimo ${ }^{44}$ cobraria un significado político muy acentuado. Porque si «de la consciència imperial d'Alfons el Magnànim, en sabem molt poca cosa $\aleph^{45}$, el Curial prodría estar ofreciéndonos un valioso testimonio y perfilarnos el ideal de la romanitas ${ }^{46}$ en un autor que emulaba la Eneida - como era sabido- con su obra. Pero -creo- para nuestro autor ésta no sería solamente un modelo épico ennoblecedor que proporcionase paralelismos sino que, como había hecho el poeta latino con los griegos, amoldaría la epopeya virgiliana a una nueva situación, asimilándola plenamente. Como había hecho con la Comedia y como parece ser que hacía con la narrativa francesa de una manera más difuminada.

Observemos además en la profecía la mención de la Envidia, figura maléfica tan importante en el Curial, provocadora de disturbios morales desde el inicio hasta el final de la obra. (Hasta el rey de Túnez hizo echar dos leones contra Curial porque estaba rabioso de envidia. $Y$ hasta que no la supera Güelfa, rechazándola en una personificación de vieja repugnante en un sueño, no se resuelve la novela).

He dejado para el final un par de detalles: uno, el verso 105, discutidísimo desde los orígenes de la exégesis de la Comedia. Sólo cabe apuntar si

42 En la Eneida la nota profética aparece desde el comienzo, en que se anuncia el decreto de las Parcas que Juno había oído. De Virgilio pasó a la Comedia. Parece, pues, coherente con la línea de influencias que el autor catalán hubiese recogido también el elemento de la profecía para su héroe.

4.7 Que la figura de Eneas sirve para engrandecer a Curial y que en algunos aspectos lo supera ya lo vio la Dra.Badía (véase el último trabajo citado, p. 18). En cuanto a la idea de un pacificador podia ser oportunísima, ya que la paz era una finalidad según la doctrina de los humanistas. El Magnánimo mismo intentaba seguir este criterio (véase J. RuBló i BALAGUER, "Alfons el Magnànim i la reina Maria», en La cultura catalana del Renaixement a la Decadéncia, Barcelona, ed. 62, 1964, pp. 53-54.

4 Tengo que remitir una vez más -y me excuso definitivamente- a otro trabajo de J. ButIN̂A: "Si Curial fos Alfons IV», que aparecerá en la Revista de Literatura Medieval el año próximo.

${ }_{45}$ J. ViCENS Vives, Els Trastàmares, Barcelona, ed. Vicens Vives, 2." ed., p. 132.

46 Hay que tener presentes las inscripciones en latín y los dísticos en honor al Mecenas por parte de los humanistas de la corte de Nápoles (ibidem, p. 131). 
hace referencia a la ciudad de Feltro y a Montefeltro ${ }^{47}$, el monte contiguo, lo que podría indicarnos un juego de palabras entre Montefeltro y Monferrato. En tal caso, la nación en que se adscribe Curial recordaría el nombre de la del vencedor de la fiera. Pero este punto no es tan simple pues los versos dantescos se interpretan generalmente como la indicación del lugar de origen. $Y$ en tal caso nos hallamos ante las siguientes posibilidades: ¿es un dato positivo que no se concrete el de Curial ante la vaguedad de la referencia dantesca?, ¿es ésta una vía muerta al no especificarse la procedencia de Curial?, ¿es sintomático en cualquier caso que ambos sean héroes subalpinos?

Por último, la alusión al mastín. En realidad es un lebrel, en italiano veltro. $Y$ en la puerta de la tienda que regaló Laquesis a Curial, rodeado de un lema amoroso había «un lebrer blanch molt ben fet, qui semblava fos viun ${ }^{48}$.

En la Comedia hay más referencias a la familia Della Scala, a quienes iba dirigida la profecía según parece ${ }^{49}$. Como en el canto XVII del Paraíso, en que se hace referencia al "gran Lombardo" que ulleva el ave sagrada" (versos 70-72) y que había nacido bajo el signo de Marte, bajo «el influjo de esta estrella fuerte» (verso 77). Estas connotaciones podrían ser adecuadas también para Curial, a quien caracteriza por su oficio el signo de Marte al comienzo del II volumen, quien era considerado «lombart per adopció» y lleva en su escudo algo indefinido: águila, milano o halcón. Es decir, un ave $^{50}$. Precisamente desdibujado.

Si interpretamos que se están aplicando a Curial tales notas proféticas habrá que mirar con especial atención la epistola a Cangrande della Scala, señor de Verona y protector de Dante. Sin ahondar aquí en el tema, hay que apuntar que la explicación que da Dante para la Comedia en el aspecto técnico es sumamente adecuada para entender el III libro del Curial (así, la estética simétrica $^{51}$, la multitud de sentidos, el dominio de la metáfora, etc.).

${ }_{47}$ Esta es la primera hipótesis que presenta la Enciclopedia Dantesca, vol. II, Roma, ed. Inst. Enciclopedia Italiana, p. 833. Sin embargo, en la traducción que venimos siguiendo se interpreta como una alusión a la pobreza del futuro héroe. (El verso en cuestión es: «e sua nazion sarà tra feltro e feltroy).

48 Véase la edición de Aramon del Curial, vol. II, p. 106 (en la traducción de Gimferrer se ha omitido esta línea; véase la p. 187). Parece que volvía a salir el lebrel en el bordado de la manga de Laquesis (véase la nota de Aramon en la p. 266 del vol. III).

4 Véase la Enciclopedia Dantesca, op. cit., pp. 351-360.

so Para la última referencia, véanse las pp. 33 y 185 del Curial y Güelfa; para la anterior, Una reina per a Curial, op. cit., p. 20.

"La Dra.Badia, ante una de estas situaciones, dice que se produce uuna mena de disposició concèntrica d'episodis, gairebé com en una capsa xinesa" ("La segona visió mitològica de Curial», art. cit., p. 270). Esta epístola vierte asimismo luz sobre el discurso prologal al III volumen del Curial; véase un aspecto en esta cita: «los poetas necesitan una larga invocación ya que deben postular a los espíritus superiores algo que sobrepuja la común posibilidad de 
Y cuando el florentino separa claramente un tercer libro para su prócer, y el III del Curial se diferencia claramente de los otros dos y desde finales del II hay en la novela exclamaciones directas autor-lector (pp. 290-293) y comienza el III decididamente dirigiéndose a un tú directo, cabe preguntarse si este III volumen iba a ser dedicado especialmente a alguien, al que también se le hubieran aplicado los signos de la profecia dantesca.

Tanto en el Curial como en la Comedia, sin embargo, predomina la unidad del conjunto. Según Dante, la finalidad del todo y de la parte es la misma: «apartar a los mortales, mientras viven aquí abajo, del estado de la miseria y llevarlos al estado de felicidad $"{ }^{52}$. Una diferencia importante entre ambas obras, desde este punto de vista, radica en que el autor catalán no dedica el III volumen sólo al Premio. Incluía además toda la purgación. Una vez más se nos definiría el Curial como una obra de tono triunfal, pero eminentemente didáctica. Ello explicaría la contradictoria interpretación que desconcertaba hasta el presente. La novela podía incluir ambos aspectos: si aplicamos la profecía a Curial, es obvio que lo encumbraba; y si detrás de Curial está Alfonso V, se hace patente la gran admiración del autor por su monarca. Ahora bien, no hay que olvidar el sentido didáctico, de advertencia, riña incluso, de la obra. Sea en el papel de Melchor, o más aún en el de Baco, cuya reprimenda va a obtener la conversión de Curial, que le llevará a su Premio final.

Cabe preguntarse ya y por muchos motivos, pues, por qué, en el punto álgido de la obra, Baco cita a san Gregorio - lo cual es ciertamente inusitado-, ya que ello podría darnos la clave de interpretación del pasaje.

Si un libro sigue tan de cerca la Divina Comedia ${ }^{53}$ hay que preguntarse ineludiblemente qué papel hace en ella el gran Papa. Ante una extravagancia de cualquier obra, si se ciñe estrechamente a una fuente, hay que acudir a ésta a la búsqueda de una posible explicación. Y he aquí que la mención de san Gregorio en la Divina Comedia, no sólo es plenamente congruente con los supuestos establecidos sino que descifra la aparente incongruencia de un Papa hablando por boca de un dios pagano.

Me limitaré a exponer los versos relativos con un breve comentario explicativo de su sentido. En el canto $X$ del Purgatorio se explica una anécdota que estaba allí representada sobre la justicia del Emperador Trajano. Y se

los hombres, es decir un don casi divino. Por esto, el presente prólogo está dividido en dos partes; en la primera se anuncia lo que se va a decir, en la segunda se invoca a Apolo". (Obras Completas, op. cit., p. 817).

${ }^{52}$ Ibidem, p. 816.

${ }^{33}$ Por encima de los aspectos formales interesa atender a los conceptuales. Creo que los versos 103-141 del canto I del Paraiso son claves para entender la rapidez de la conversión de Curial y el vertiginoso efecto de las palabras de Baco, porque ilustran la reconstitución natural de la tendencia hacia Dios. Se trata, pues, de volver a la vía que encauza al hombre dentro del orden del Universo, alterado sólo por el pecado. 
hace referencia a una leyenda, muy propagada antiguamente, según la cual, el Papa san Gregorio Magno, fuertemente admirado de la virtud del Emperador, aunque como gentil no se podía salvar, consiguió la gran victoria de que Trajano fuese liberado del infierno: «Alli estaba historiada la alta gloria del príncipe romano cuyo mérito movió a Gregorio para que alcanzase su gran victoria; quiero decir el emperador Trajano" ${ }^{54}$.

En el canto XX del Paraíso se explica lo que parece increíble: la razón del poder fulminante que hizo que Trajano se liberase de aquel lugar irreversible. Esto es, la fuerza de las palabras del santo y su vivísima esperanza: "Veo que crees estas cosas porque yo te las digo, pero no ves la razón, de modo que, si son creídas, están ocultas. Haces como el que aprende bien las cosas por su nombre, pero no puede ver su esencia si otro no se la explica. Regnum caelorum sufre violencia del cálido amor y de la viva esperanza, que vence a la divina voluntad no a la manera que el hombre sobrepuja al hombre, sino que la vence porque ella quiere ser vencida, y al serlo, vence, a su vez, con su benignidad. La primera y la quinta alma del arco de la ceja te asombran porque ves con ellas adornada la región de los ángeles. De su cuerpo no salieron, como crees, gentiles, sino cristianos con firme fe, una en los pies que habían de ser clavados, otra en los que ya lo habían sido" ${ }^{55}$.

La admiración de san Gregorio por Trajano, el emperador que marcó la cumbre de las conquistas romanas, así como la fuerza de su ruego, hicieron la ayuda del Papa eficaz: "Una de ellas, desde el infierno, de donde no se vuelve jamás por propia voluntad, volvió al cuerpo, y esto fue el premio de una viva esperanza; de una viva esperanza que elevó ruegos a Dios para que la resucitase, de modo que su voluntad pudiera ser movida. El alma gloriosa de la que se habla, vuelta a la carne, en la que estuvo poco tiempo, creyó en aquel que podía ayudarla, y creyendo encendióse con tanto fuego de verdadero amor, que por la segunda muerte fue digna de venir a este gozo" ${ }^{56}$.

Cabe preguntarse si estos versos podian dar razón del infierno de donde

54 Versos 73-76, p. 240 de la ed. BAC. La anécdota que se explica, que deja patente la justicia de aquel Emperador, se narra también en el Breviloquio de Juan de Gales, manual de doctrina política que parece que el autor catalán consultaba (véase la nota de Aramon al respecto en el vol. III de su edición, p. 270).

${ }_{s 3}$ Versos 94-105, p. 465 de la ed. BAC. El otro espíritu que se cita en el verso 100 es el de Rifeo, un troyano amantísimo de la justicia.

so Versos 106-107, p. 466 de la ed. BAC. Puede interesar el comentario que se da a los versos 106-111 en la edición de "Els Nostres Clàssics", la cual recoge la versión del siglo xv de Andreu Febrer: "Trajà ressuscità de l'infern, d'on hom no torna mai a voler el bé. Áquest fou el premi de la viva esperança de sant Gregori, que ho havia demanat a Déu:d'una esperança tan forta que pogué mudar la divina voluntat amb les seves oracions» (vol. VI, Barcelona, ed. Barcino, 1988, p. 44). Y también el que se da en la edición que seguimos, en el verso 117 : "Grande ha sido el esfuerzo que ha tenido que realizar Dante para salvar a Trajano; nada menos que resucitarlo, sacándolo del infierno, y haciéndolo vivir y morir por segunda vez». 
salió nuestro héroe literario, así como si podrían explicar el eufórico triunfalismo del Curial. Ahora bien, este autor, en su humanización de la $\mathrm{Co}$ media, y siguiendo una dinámica muy afin al escritor florentino, para lograr ser eficiente podía haber concentrado todo su esfuerzo en la belleza formal y conceptual de su obra, lo que sí podía conmover y convencer a un humanista ${ }^{57}$.

Esta interpretación de la cita de san Gregorio Magno en la resolución de la novela, con fundamento en un fragmento de la Divina Comedia que trata de la predestinación, supondría un fecundo y profundo contrapunto al planteamiento inicial del volumen sobre el poder caído de la diosa Fortuna. Lo cual abriría a esta novela caballeresca una brecha importante en una nueva y grave dimensión.

Con ello, el Curial marcaría una muy precisa coyuntura, en que se admira plenamente a Dante y se le considera la vía a seguir, en base a su cientifismo y armonía del Universo, pero ya no es la perspectiva religiosa de aquél la predominante, sino otra, que se manifiesta a través de Baco.

${ }^{57}$ En cuanto a aspectos formales de la cita de san Gregorio: las palabras exactas - aunque son plenamente idóneas - cuesta localizarlas entre sus obras. Hay que tener en cuenta, de todos modos, que en el sueño el santo ejerceria exclusivamente una función; la forma visual es el dios Baco y la literaria podría, por ejemplo, inspirarsu - ipor qué no una extravagancia paralela? - en Petrarca, que quizá es la forma preferida por el autor, ya que al parecer a su sombra se inicia el Curial (véase "Sobre l'autoria del Curial e Güelfa», art. cit., pp. 76-77, en que me fundo para insinuarlo en una iniciativa del Dr. Francisco Rico). Un último comentario al respecto, ya que puede considerarse sintomático en cuanto a puntos tratados aquí: el prólogo a De Remediis, donde se observaria este calco recientemente mencionado, era una epístola a Azzo da Correggio, nombre que permitia a Petrarca jugar con cor regium. No es ningún dato definitivo, evidentemente, pero sí un pequeño tanto más, significativo en la asociación Alfonso V-Curial. 